\title{
Circulating Antibodies against Avian Influenza and Newcastle Disease in Semi-Captive Peacocks in Southwestern Guatemala
}

\author{
Melissa Castillo-Grijalva ${ }^{1}$, Dennis Guerra-Centeno ${ }^{1 *}$, Yousef Talgi ${ }^{1}$, Carlos Valdez-Sandoval $^{1}$, \\ Manuel Lepe-López ${ }^{1}$, and Beatriz Santizo ${ }^{2}$ \\ ${ }^{1}$ Instituto de Investigación en Ciencia Animal y Ecosalud, Facultad de Medicina Veterinaria y Zootecnia, Universidad de \\ San Carlos de Guatemala, Ciudad Universitaria zona 12, 01012, Guatemala City, Guatemala. \\ ${ }^{2}$ Laboratorio de Regional de Referencia de Sanidad Animal, Facultad de Medicina Veterinaria y Zootecnia, Universidad de \\ San Carlos de Gutemala, Ciudad Universitaria zona 12, 01012, Guatemala City, Guatemala. \\ *Corresponding author's Email: msc.dennisguerra@gmail.com; ORCID: 0000-0002-3021-4742
}

Received: 01 Jul. 2020

Accepted: 15 Aug. 2020

\begin{abstract}
Avian Influenza and Newcastle disease are the two most important diseases of poultry and are globally considered as threats to public health and economy. There is little information published about these diseases in peacocks and other common backyard poultry in Guatemala. Therefore, an exploratory serosurvey was conducted to determine the presence of circulating antibodies to Avian Influenza (AI) and Newcastle Disease (ND) viruses in a semi-captive population of peacocks in southwestern Guatemala. Additionally, the circulation of antibodies to these pathogens in backyard chickens, ducks, and turkeys from a neighboring community was explored. Blood samples were obtained from 48 peacocks, 30 chickens, 6 ducks, and 4 turkeys. The samples were processed in the Regional Reference Laboratory for Animal Health, at the Veterinary Medicine Faculty, University of San Carlos of Guatemala, located in Guatemala City. Antibodies against AI virus were investigated by Agar Gel Immunodiffusion, and antibodies against ND virus were examined using Hemagglutination Inhibition. No antibodies against AI virus were detected. Most of the samples (97.7\%) were negative for antibodies against ND virus, except for two turkeys that carried low antibody titers. The findings of the present study indicate that no virulent strains of AI or ND viruses were circulating in the investigated site.
\end{abstract}

Keywords: Avian influenza, Epidemiology, Newcastle disease, Serology, Zoonoses

\section{INTRODUCTION}

Avian Influenza (AI) and Newcastle Disease (ND) are the most important diseases of poultry (Alexander, 2000; Capua and Marangon, 2006), and are considered global threats to public health and economy (Wong and Yuen, 2006). AI viruses have been a common cause of epidemics and pandemics (De Jong and Hien, 2006; Alexander, 2007; Peiris et al., 2007; Monto and Fukuda, 2020), and their ability to mutate and become more pathogenic or more capable to invade other host species makes them relevant to animal and public health.

Due to this mutation capacity, numerous subtypes of influenza A virus have evolved. On the other hand, Newcastle disease is one of the threats to farm economy and poultry production, not only because it causes economic losses due to mortality, but also because many countries have sanitary barriers that prohibit importations from countries where the disease is endemic (Miller and Koch, 2013). Both AI and ND are known to affect a wide variety of hosts (Stallknecht and Shane, 1998; Ito and Kawaoka, 2000; Baigent and McCauley, 2003; Swayne and King, 2003). These pathogens have already been found in Guatemala in some avian species in certain areas of the country (Gonzalez-Reiche et al., 2016; Mérida et al., 2016; Gonzalez-Reiche et al., 2017). However, published information about AI or ND in peacocks or backyard fowl species in southwestern Guatemala is practically inexistent.

In response to this gap of knowledge, the presence of circulating antibodies against $\mathrm{AI}$ and $\mathrm{ND}$ viruses was investigated in a semi-captive population of peacocks in southwestern Guatemala. Additionally, the circulation of antibodies against these pathogens was explored in backyard chickens, ducks, and turkeys from a neighboring community. 


\section{MATERIALS AND METHODS}

\section{Study site}

A population of 94 peacocks (Pavo cristatus) kept in semi-captive conditions in an amusement park located at Retalhuleu department, in southwestern Guatemala (coordinates 14³5'41" N 91 $36^{\circ} 42^{\prime \prime} \mathrm{W}$ ) was studied. The study site was a fenced area of 128 thousand square meters surrounded by small villages and hamlets where peasants strongly depend on family agriculture and animal raising to survive (Figure 1). In the park facilities, peacocks roamed freely among visitors (one million visitors a year), and frequently came into the contact with wild birds. To explore the antibody circulation in the surroundings, a sample of backyard fowl was also studied in households of the neighboring community, San Martín Zapotitlán, Retalhuleu, Guatemala.

\section{Species and sampling}

A sample of 48 peacock individuals was calculated and randomly sampled based on 50\% prevalence, $95 \%$ confidence interval, and 0.1 margin of error. Additionally, thirty chickens (Gallus gallus), four turkeys (Meleagris gallopavo), and six ducks (Anas platyrhynchos) were sampled by convenience. All sampled birds were adults. Three millimeters of blood was taken from the ulnar vein using 3cc syringes with $23 \mathrm{~g} \mathrm{X} 1.5$ " needles, while gently holding the birds by hand. The blood samples were put into test tubes without anticoagulant, centrifuged for four minutes at 3,000 rpm, transferred to plastic straws, and transported to be processed in the Regional Reference Laboratory for Animal Health (Larrsa), at the Veterinary Medicine and Animal Husbandry Faculty, University of San Carlos of Guatemala, in Guatemala City.
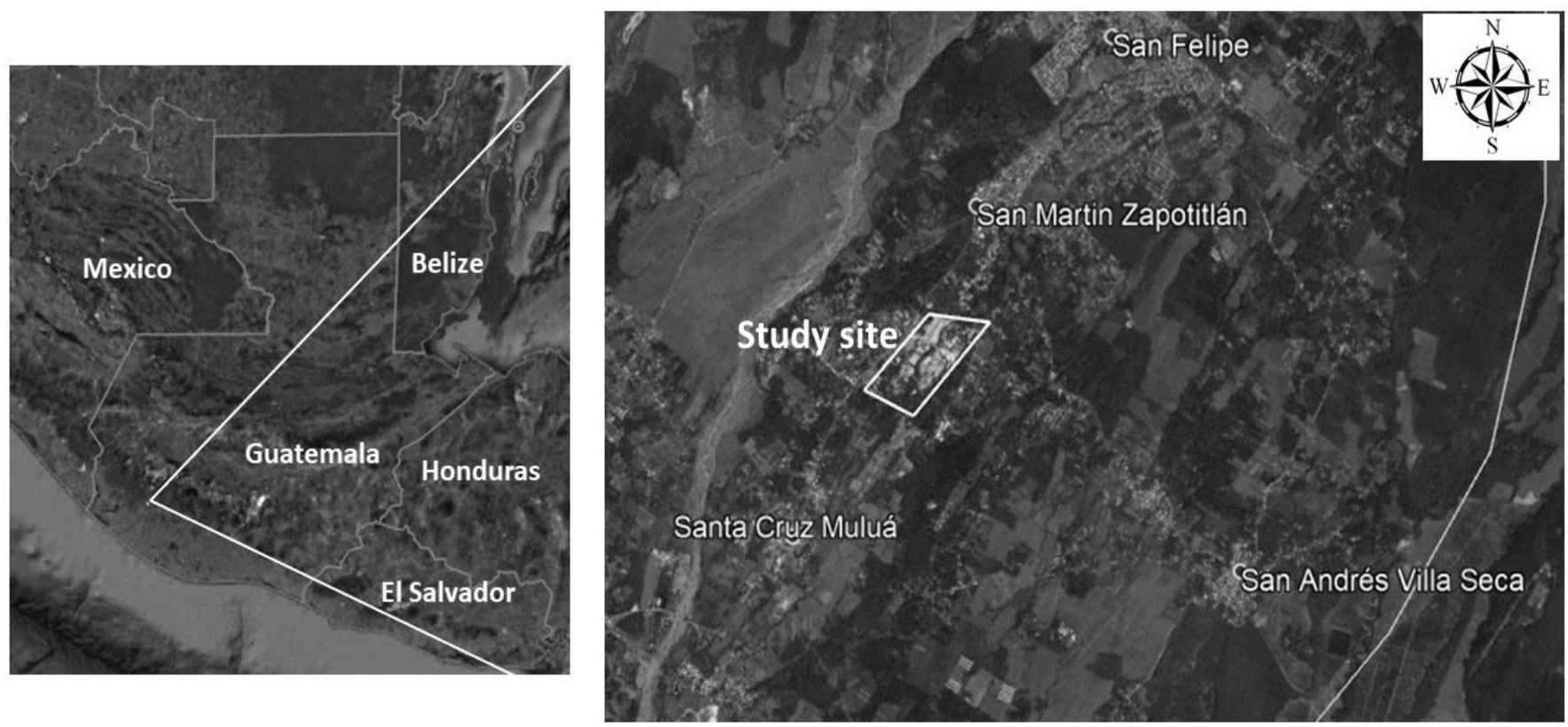

Figure 1. Study site location in Retalhuleu, southwestern Guatemala.

\section{Laboratory procedures}

Antibodies against AI virus were studied by agar gel immunodiffusion (GID) tests, performed according to standard procedures (OIE, 2018a), using Type I molecular biology grade agarose (Calbiochem, USA), $\mathrm{NaCl}$ and $\mathrm{pH}$ 7.2 phosphate buffer (Merk, Germany) and AI antigen (Larrsa, Guatemala).

Antibodies against ND virus were studied by hemagglutination inhibition tests performed according to standard procedures (OIE, 2018b), using a 1\% chicken red blood cell solution (Larrsa, Guatemala), local ND antigens
(Larrsa, Guatemala) isotonic PBS (Merk, Germany), positive control (Charles Rivers, USA), 10-100 $\mu$ l unichannel micropipettes (Transferpette, Germany), 10$100 \mu \mathrm{l}$ multichannel micropipettes (Transferpette, Germany), micropipette tips (Transferpette, Germany) Vbottomed microtiter plates (Nunc, Denmark) and an orbital shaker (Barnstead, Germany). HI antibody titers were considered positive if there was inhibition of hemagglutination at serum dilutions of $1 / 16\left(2^{4}\right.$ or $\log _{2} 4$, when expressed as the reciprocal, as is customary in Larrsa). 


\section{Ethical approval}

This research was approved by the Bioethics Committee of the Graduate School, Veterinary Medicine and Animal Husbandry Faculty, University of San Carlos of Guatemala.

\section{RESULTS AND DISCUSSION}

No circulating antibodies against $\mathrm{AI}$ and ND viruses were found in the sampled peacocks. Antibodies were also not found in the backyard birds of the neighboring community, except for two turkeys that had low antibody titers ( $\log _{2} 5$ and 6) against ND virus (Table 1$)$.

Table 1. Frequency of positive blood samples to antibodies against Avian Influenza and Newcastle disease in peacocks.

\begin{tabular}{lccc}
\hline Bird species & $\begin{array}{c}\text { Number } \\
\text { of samples }\end{array}$ & $\begin{array}{c}\text { Avian } \\
\text { Influenza } \\
\text { antibodies }\end{array}$ & $\begin{array}{c}\text { Newcastle } \\
\text { Disease } \\
\text { antibodies }\end{array}$ \\
\hline Pavo cristatus & 48 & 0 & 0 \\
\hline Gallus gallus & 30 & 0 & 0 \\
\hline Meleagris gallopavo & 4 & 0 & 2 \\
\hline Anas platyrhynchos & 6 & 0 & 0 \\
\hline Total & 88 & 0 & 2 \\
\hline
\end{tabular}

Note: the titers of the positive Meleagris gallopavo samples were 5 and 6 ( $\log _{2}$ reciprocal).

Although peacocks are susceptible to some AI and ND virus strains (Munir et al., 2012; Desingu et al., 2016; Umar, 2017; Wajid et al., 2017), and even though the studied population was kept in semi-captive conditions and in frequent contact with people, and wild birds that were possible sources of infection (Rehan et al., 2019), no antibodies were found in the sampled individuals. It was also highly likely that the rest of the population did not have antibodies either, especially considering that the entire flock slept every night at the same roosting site, and therefore, if the population were susceptible, any outbreak of AI or ND would have readily spread due to disease ecology determinants (Beldomenico and Begon, 2010).

The absence of antibodies against AI virus observed in the sampled peacocks in the present study was consistent with previous studies in the USA by Hollamby et al. (2003) and in Hong Kong by Ellis et al. (2004), but inconsistent with studies in the Kingdom of Saudi Arabia by Ismail et al. (2010) and in Iraq by Rashid et al. (2017). On the other hand, the absence of antibodies against ND virus was consistent with the findings of Ibitoye et al. (2013) in Nigeria, and inconsistent with the findings of Vijayarani et al. (2010), Khulape et al. (2014) and Desingu et al. (2016) in India; Sadiq et al. (2011) in Nigeria; Chumbe et al. (2015) in Peru and Munir et al. (2012) and Mustafa et al. (2015) in Pakistan.

The first interesting consideration when interpreting our findings was that GID test is a screening assessment that detects antibodies against all subtypes of AI virus (Jenson, 2014). In that sense, there was not only the absence of antibodies against the previously isolated subtypes in Guatemala, but also against all subtypes. The second consideration would be the cause underlying the absence of antibodies in almost all the sampled birds (including the backyard poultry from the neighboring community). Failure to find antibodies could mean that past epizootic outbreaks have swept birds -as has been previously reported in Guatemala (Lepe-López et al., 2020) - and have left no immune history. It could also mean that the circulating virus strains were not pathogenic enough to stimulate the production of antibodies in the studied birds. It has also been suggested that in backyard poultry, a lack of immune response could be the result of infectious bursal disease, chronic aflatoxicosis, or vitamin A deficiency (Awan et al., 1994). However, this was unlikely to be the underlying cause, at least in the case of the peacocks, because the population had veterinary care and adequate nutritional management.

The lack of evidence of the circulation of virulent strains of AI and ND viruses in the studied landscape is epidemiologically noticeable considering that in Guatemala, more than 26 million backyard chickens are being raised -and probably being trade- in practically all the country (Ministry of Agriculture, Livestock and Food, Guatemala, 2015). In fact, antibodies against AI and ND viruses have been detected in some backyard chicken populations (Aguilar-Miller et al., 2016; AquinoSagastume et al., 2016; Mérida-Ruiz et al., 2016) as well as in commercial poultry (Lee et al., 2004) and in wild birds (Gonzalez-Reiche et al., 2012; Gonzalez-Reiche et al., 2016). On the other hand, 758 species of birds are distributed in Guatemala, and at least 240 are migratory (Eisermann and Avendaño, 2018). This host diversity seems to be accompanied by a virus diversity because recently, 19 Influenzavirus A subtypes were isolated from migratory ducks in Guatemala, including the H7N3 subtype (Gonzalez-Reiche et al., 2017).

It is important to notice that, depending on the virus strain and the avian host species, some low pathogenicity $\mathrm{AI}$ viruses are unable to infect hosts stimulating only low or imperceptible immune responses (Alexander et al., 1978; Alexander et al., 1986). This differential speciesdependent immune response was also observed for the ND 
virus (Eze et al., 2014). During an H5N1 AI outbreak in a natural park in Hong Kong, several species of birds resulted infected, but peacocks were among the nonaffected species (Ellis et al., 2004).

The absence of antibodies in the backyard poultry of the neighboring community found in the present study could mean that no virulent strains of $\mathrm{AI}$ or ND viruses were circulating in the landscape. In a backyard poultry national Serosurvey for AI and ND in Oman, the bird seroprevalence was $37.5 \%$ and $42.1 \%$ respectively, and the flock seroprevalence was $84 \%$ and $90 \%$ respectively (Al Shekaili et al., 2015) but this massive seroprevalences seemed unlikely for Guatemala where previous data suggest a patchy distribution of these pathogens in the backyard poultry population.

On the other hand, the finding of two seropositive turkey individuals to antibodies against ND virus in the present study is rather difficult to explain, considering that all the other sampled specimens did not show circulating antibodies against ND virus. These two antibody-carrier turkeys could have been recently added to the population by the peasants.

Considering the evidence found in the present study, more research needs to be done to establish the distribution pattern of Influenza and Newcastle viruses in the avian host populations throughout the country, mainly, at the human-animal interface (Chaudhry et al., 2020). This would enable the design of sound intervention policies to assure commercial and backyard poultry productivity and public health.

\section{CONCLUSION}

Considering that the population was not recentlyestablished and based on the absence of antibodies and on the fact that no significant mortality was observed in recent years, the results indicate that no AI or ND viruses are circulating in the studied population of peacocks.

\section{DECLARATIONS}

\section{Acknowledgements}

The researchers want to thank Dr. Karen Calderón for collaborating in the laboratory procedures.

\section{Competing interests}

The authors have declared that no competing interest exists.

\section{Consent to publish}

The authors grant the publisher the sole and exclusive license of the full copyright in the contribution. Consequently, the publisher shall have the exclusive right throughout the world to publish and sell the contribution in all languages and all other forms of electronic publication.

\section{Author's contribution}

MC-G conception of the idea, drafting the manuscript and field sampling DG-C conception of the idea, drafting and editing the manuscript YT field sampling and reviewing the manuscript CV-S and ML-L conception of the idea and reviewing the manuscript BS laboratory procedures, and reviewing the manuscript. All authors checked and confirmed the final version of the article.

\section{REFERENCES}

Aguilar-Miller H, Guerra-Centeno D, Valdez-Sandoval C, Monterroso P and García-Anleu R (2016). Estudio serológico de anticuerpos contra patógenos comunes, en gallinas de patio de la aldea El Caoba, Reserva de la Biosfera Maya, Guatemala. Revista Naturaleza, Sociedad y Ambiente, 3: 95-106. DOI: https://doi.org/10.37533/cunsurori.v3i1.18

Al Shekaili T, Clough H, Ganapathy K and Baylis M (2015). Serosurveillance and risk factors for avian influenza and Newcastle disease virus in backyard poultry in Oman. Preventive Veterinary Medicine, 122(1-2): 145-153. https://doi.org/10.1016/j.prevetmed.2015.09.011

Alexander DJ (2000). Newcastle disease and other avian paramyxoviruses. Revue Scientifique et Technique-Office International des Epizooties, 19(2): 443-455. DOI: https://doi.org/10.20506/rst.19.2.1231

Alexander DJ (2007). An overview of the epidemiology of avian influenza. Vaccine, 25(30): 5637-5644. DOI: https://doi.org/10.1016/j.jcv.2005.09.002

Alexander DJ, Allan WH, Parsons DG and Parsons G (1978). The pathogenicity of four avian influenza viruses for fowls, turkeys and ducks. Research in veterinary science, 24(2): 242-247. DOI: https://doi.org/10.1016/S0034-5288(18)33080-7

Alexander DJ, Parsons G and Manvell RJ (1986). Experimental assessment of the pathogenicity of eight avian influenza A viruses of H5 subtype for chickens, turkeys, ducks and quail. Avian pathology, 15(4): 647-662. DOI: https://doi.org/10.1080/03079458608436328

Aquino-Sagastume E, Guerra-Centeno D, Valdez-Sandoval C, Villatoro F, Villatoro D and Santizo B (2016). Exploratory Serosurvey for antibodies to avian pathogens in backyard chickens from a satellite community of Jalapa City, Guatemala. Ciencia, Tecnología y Salud, 3(2): 5-13. DOI: http//dx.doi.org/10.36829/63CTS.v3i2.\%25

Awan MA, Otte MJ and James AD (1994). The epidemiology of Newcastle disease in rural poultry: a review. Avian pathology, 23(3): 405-423. DOI: https://doi.org/10.1080/03079459408419012

Baigent SJ and McCauley JW (2003). Influenza type A in humans, mammals and birds: Determinants of virus virulence, host-range and interspecies transmission. Bioessays, 25(7): 657-671. DOI: https://doi.org/10.1002/bies.10303 
Beldomenico PM and Begon M (2010). Disease spread, susceptibility and infection intensity: vicious circles? Trends in Ecology \& Evolution, 25(1): 21-27. DOI: https://doi.org/10.1016/j.tree.2009.06.015

Capua I and Marangon S (2006). Control of avian influenza in poultry. Emerging Infectious Diseases, 12(9): 1319-1324. DOI: https://doi.org/10.3201/eid1209.060430

Chaudhry M, Webby R, Swayne D, Bin Rashid, H, DeBeauchamp J, Killmaster L, Ferreira M, Lee D, Webb A, Yousaf S et al. (2020). Avian influenza at animal-human interface: One-health challenge in live poultry retail stalls of Chakwal, Pakistan. Influenza and Other Respiratory Viruses, 14(3): 257-265. DOI: https://doi.org/10.1111/irv.12718

Chumbe A, Izquierdo-Lara R, Tataje-Lavanda L, Figueroa A, Segovia K, Gonzalez R, CribilleroG, Montalvan A, Fernández-Díaz M Icochea E et al. (2015). Characterization and sequencing of a genotype XII Newcastle disease virus isolated from a peacock (Pavo cristatus) in Peru. Genome Announc., 3(4): e00792-15. DOI: https://doi.org/ 10.1128/genomeA.00792-15

De Jong MD and Hien TT (2006). Avian influenza A (H5N1). Journal of clinical virology, 35(1): 2-13. https://doi.org/10.1016/j.jcv.2005.09.002

Desingu PA, Singh SD, Dhama K, Vinodhkumar OR, Barathidasan R, Malik YS, Singh R and Singh RK (2016). Molecular characterization, isolation, pathology and pathotyping of peafowl (Pavo cristatus) origin Newcastle disease virus isolates recovered from disease outbreaks in three states of India. Avian Pathology, 45(6): 674-682. DOI: https://doi.org/10.1080/03079457.2016.1198005

Eisermann K and Avendaño C (2018). An update on the inventory, distribution and residency status of bird species in Guatemala. Bulletin of the British Ornithologists' Club, 138(3): 148-229. DOI: https://doi.org/10.25226/bboc.v138i3.2018.a2

Ellis TM, Bousfield RB, Bissett LA, Dyrting KC, Luk, GS, Tsim ST, Sturm-ramirez K, Webster RG, Guan Y et al. (2004). Investigation of outbreaks of highly pathogenic $\mathrm{H} 5 \mathrm{~N} 1$ avian influenza in waterfowl and wild birds in Hong Kong in late 2002. Avian Pathology, 33(5): 492-505. DOI: https://doi.org/10.1080/03079450400003601

Eze CP, Shoyinka VS, Okoye JOA, Ezema WS, Ogbonna IO, Eze DC, Okwor RC and Ikejiofor OK (2014). Comparison of the serum proteins and immune responses of velogenic Newcastle disease virus infected chickens and ducks. Open Journal of Veterinary Medicine, 4: 122-128. DOI: https://doi.org/ 10.4236/ojvm.2014.46014

Gonzalez-Reiche AS, Morales-Betoulle ME, Alvarez D, Betoulle JL, Müller ML, Sosa SM and Perez DR (2012). Influenza A viruses from wild birds in Guatemala belong to the North American $\begin{array}{lll}\text { lineage. PloS one, 7(3): } & \text { e32873. }\end{array}$ https://doi.org/10.1371/journal.pone.0032873

Gonzalez-Reiche AS, Müller ML, Ortiz L, Cordón-Rosales C and Perez DR (2016). Prevalence and diversity of low pathogenicity avian influenza viruses in wild birds in Guatemala, 2010-2013. Avian diseases, 60(1s), 359-364. DOI: https://doi.org/10.1637/11130050715-Reg

Gonzalez-Reiche AS, Nelson MI, Angel M, Müller ML, Ortiz L, Dutta J, Van Bakel H, Cordon-Rosales C and Perez DR (2017). Evidence of intercontinental spread and uncommon variants of lowpathogenicity avian influenza viruses in ducks overwintering in Guatemala. Msphere, 2(2): $\quad$ e00362-16. DOI: https://doi.org/10.1128/mSphere.00362-16

Hollamby S, Sikarskie JG and Stuht J (2003). Survey of peafowl (Pavo cristatus) for potential pathogens at three Michigan zoos. Journal of Zoo and Wildlife Medicine, 34(4): 375-379. DOI: https://doi.org/10.1638/03-077
Ibitoye EB, Jimoh AA and Mungadi HU (2013). A retrospective (20072011) analysis of Newcastle disease diagnosed at avian clinic of Veterinary Teaching Hospital, Usmanu Danfodiyo University Sokoto, Nigeria. Current Research in Poultry Science, 3(1): 12-17. DOI: https://doi.org/10.3923/crpsaj.2013.12.17

Ismail MM, Khan OA, Cattoli G and $\mathrm{Lu} \mathrm{H}$ (2010). Isolation and identification of highly pathogenic avian influenza virus subtype H5N1 in peafowl (Pavo cristatus). Avian Diseases, 54(s1): 357-360. DOI: https://doi.org/10.1637/9181-881409-DIGEST.1

Ito $\mathrm{T}$ and Kawaoka $\mathrm{Y}$ (2000). Host-range barrier of influenza A viruses. Veterinary microbiology, 74(1-2): 71-75. DOI: https://doi.org/10.1016/s0378-1135(00)00167-x

Jenson TA (2014). Agar gel immunodiffusion assay to detect antibodies to type A Influenza Virus. In E. Spackman (Ed.) Animal Influenza Virus, Methods in Molecular Biology, vol. 1161, Humana Press, New York, pp. 141-150. DOI: https//doi.org/10.1007/978-1-49390758-8_13

Khulape SA, Gaikwad SS, Chellappa MM, Mishra BP and Dey S (2014). Complete genome sequence of a Newcastle disease virus isolated from wild peacock (Pavo cristatus) in India. Genome Announc., 2(3): e00495-14. DOI: https://doi.org/10.1128/genomeA.00495-14

Lee CW, Senne DA and Suarez DL (2004). Effect of vaccine use in the evolution of Mexican lineage H5N2 avian influenza virus. Journal of virology, 78(15): 8372-8381. DOI: https://doi.org/ 10.1128/JVI.78.15.8372-8381.2004

Lepe-López M, Ortiz D, Gomez L, Rios L, Valdez-Sandoval C, DíazRodríguez M, Villatoro-Paz F and Guerra-Centeno D (2020). La crianza de animales domésticos de traspatio en las comunidades del lago de Atitlán, Guatemala. Ciencias Sociales y Humanidades, 7(1): in press. Available at: https://digi.usac.edu.gt/ojsrevistas/index.php/csh/article/view/931/6 89

Mérida-Ruiz SA, Guerra-Centeno D, Bailey EL, Rohn K, Kösters S and Kreienbrock L (2016). Participatory Epidemiology at the Neotropics: Study of Diseases of Backyard Livestock and Description of Hunting Patterns in Uaxactún, Maya Reserve Biosphere, Guatemala. BMC Research Notes, 9: 207. DOI: https://doi.org/10.1186/s13104-016-2009-3

Ministry of Agriculture, Livestock and Food, Guatemala (2015). Government Agreement 457-2015. September 10, 2015. Available at:

https://leyes.infile.com/index.php?id=182\&id_publicacion=50791

Miller PJ and Koch G (2013). Newcastle Disease. In D. Swayne (Editor), Diseases of Poultry, Thirteenth Edition, John Wiley \& Sons, Inc. pp. 89-107. DOI: https://doi.org/10.1002/9781119421481.ch3

Monto AS and Fukuda K (2020). Lessons from influenza pandemics of the last 100 years. Clinical Infectious Diseases, 70(5): 951-957. DOI: https://doi.org/10.1093/cid/ciz803

Munir M, Shabbir MZ, Yaqub T, Shabbir MA, Mukhtar N, Khan MR and Berg M (2012). Complete genome sequence of a velogenic neurotropic avian paramyxovirus 1 isolated from peacocks (Pavo cristatus) in a wildlife park in Pakistan. Journal of Virology, 86(23): 13113-13114. DOI: https://doi.org/10.1128/JVI.02358-12

Mustafa I, Ahmed H, Lodhi, MA, Khan ARSS, Haider W, Bostan N, Asif S, Khan MR, Qayyum M, Ali S et al. (2015). Newcastle disease as an emerging disease in peacocks of Tharparker, Pakistan. The Journal of Infection in Developing Countries, 9(08), 914-916. DOI: https://doi.org/ 10.3855/jidc.5258

OIE (2018a). World Organisation For Animal Health. Manual of Diagnostic Tests and Vaccines for Terrestrial Animals (mammals, birds, and bees), 8th Edition. Paris. p. 830. Available at: https://www.oie.int/es/normas/manual-terrestre/acceso-en-linea/

OIE (2018b). World Organisation For Animal Health. Manual of Diagnostic Tests and Vaccines for Terrestrial Animals (mammals, 
birds and bees), 8th Edition. Paris. p. 971. Available at: https://www.oie.int/es/normas/manual-terrestre/acceso-en-linea/

Peiris JM, De Jong MD and Guan Y (2007). Avian influenza virus (H5N1): a threat to human health. Clinical microbiology reviews, 20(2): 243-267. DOI: https://doi.org/10.1128/CMR.00037$\underline{06}$

Rashid PM, Saeed NM and Dyary HO (2017). Genetic characterization and phylogenic analysis of $\mathrm{H} 5 \mathrm{~N} 1$ avian influenza virus detected in peafowl in Kirkuk province, Iraq. Journal of medical virology, 89(7): 1179-1185.

https://doi.org/10.1002/jmv.24762

Rehan M, Aslam A, Khan MR, Abid M, Hussain S, Umber J, Anjum A and Hussain A (2019). Potential economic impact of Newcastle disease virus isolated from wild birds on commercial poultry industry of Pakistan: a review. Hosts Viruses, 6(1): 1-15. DOI: http://dx.doi.org/10.17582/journal.hv/2019/6.1.1.15

Sadiq MA, Nwanta JA, Okolocha EC and Tijjani AN (2011). Retrospective (2000-2009) study of Newcastle disease (ND) cases in avian species in Maiduguri, Borno State, North Eastern Nigeria. International Journal of Poultry Science, 10(1): 76-81. DOI: https://doi.org/10.3923/ijps.2011.76.81

Stallknecht DE and Shane SM (1988). Host range of avian influenza virus in free-living birds. Veterinary research communications, 12(2-3): 125-141. DOI: https://doi.org/10.1007/BF00362792

Swayne DE and King DJ (2003). Avian influenza and Newcastle disease. Journal of the American Veterinary Medical Association, 222(11): $1534-1540 . \quad$ DOI: https://doi.org/10.2460/javma.2003.222.1534

Umar S (2017). Emergence of new sub-genotypes of Newcastle disease virus in Pakistan. World's Poultry Science Journal, 73(3): 567-580. DOI: https://doi.org/10.1017/S0043933917000411

Vijayarani K, Muthusamy S, Tirumurugaan KG, Sakthivelan SM and Kumanan K (2010). Pathotyping of a Newcastle disease virus isolated from peacock (Pavo cristatus). Tropical animal health and production, 42(3): 415-419. DOI: https://doi.org/10.1007/s11250009-9436-2

Wajid A, Dimitrov KM, Wasim M, Rehmani SF, Basharat A, Bibi T, Saima A, Tahir Y, Muhammad T, Mustafa A et al. (2017). Repeated isolation of virulent Newcastle disease viruses in poultry and captive non-poultry avian species in Pakistan from 2011 to 2016. Preventive Veterinary Medicine, 142: 1-6. DOI: https://doi.org/10.1016/j.prevetmed.2017.04.010

Wong SS and Yuen KY (2006). Avian influenza virus infections in humans. Chest, 129(1): 156-168. DOI: 